\title{
A new species of the genus Pulchellodromus Wunderlich, 2012 (Aranei: Philodromidae) from Spain
}

\author{
Новый вид рода Pulchellodromus Wunderlich, 2012 \\ (Aranei: Philodromidae) из Испании
}

\section{Zoya A. Kastrygina ${ }^{1}$, Mykola M. Kovblyuk ${ }^{1,2}$, Nina Yu. Polchaninova ${ }^{3}$ 3.А. Кастрыгина ${ }^{1}$, Н.М. Ковбцюк ${ }^{1,2}$, Н.Ю. Полчанинова ${ }^{3}$}

\footnotetext{
${ }^{1}$ V.I. Vernadsky Crimean Federal University, Yaltinskaya Str. 4, Simferopol 295007, Crimea. E-mail: zoiac 21@mail.ru; kovblyuk@mail.ru ${ }^{2}$ T.I. Vyazemski Karadag Scientific Station - Nature Reserve of the Russian Academy of Sciences, Nauki Str., 24, Kurortnoe Vil., Feodosiya 298188, Crimea.

${ }^{3}$ V.N. Karazin Kharkiv National University, 4, Svobody sq., Kharkiv 61022, Ukraine. E-mail: polchaninova@mail.ru

${ }^{1}$ Крымский федеральный университет им. В.И. Вернадского, ул. Ялтинская 4, г. Симферополь 295007, Крым.

${ }^{2}$ Карадагская научная станция им. Т.И. Вяземского - природный заповедник РАН, ул. Науки 24, пос. Курортное, г. Феодосия 298188, Крым.

${ }^{3}$ Харьковский национальный университет им. В.Н. Каразина, пл. Свободы 4, г. Харьков 61022, Украина.
}

KEY WORDS: spiders, Pulchellodromus, new species, description, Spain.

КЛЮЧЕВЫЕ СЛОВА: пауки, Pulchellodromus, новый вид, описание, Испания.

ABSTRACT. A new species, Pulchellodromus navarrus sp.n., from Navarre (Spain) is described. Diagnostic drawings of the new species and its habitat preferences in Spain are provided.

РЕЗЮМЕ. Новый вид Pulchellodromus navarrus sp.n., описан из Наварры (Испания). Для нового вида приводится диагностические рисунки и биотопическая приуроченность в Испании.

\section{Introduction}

At present, the genus Pulchellodromus Wunderlich, 2012 contains 12 species [Kastrygina, Kovblyuk, 2014; WSC, 2016]: P. afroglaucinus (Muster et Bosmans, 2007); P. bistigma (Simon, 1870); P. glaucinus (Simon, 1870); P. lamellipalpis (Muster, 2007); P. mainlingensis ( $\mathrm{Hu}$ et $\mathrm{Li}, 1987) ;$ P. medius (O. Pickard-Cambridge, 1872); P. pardalis (Muster et Bosmans, 2007); P. pulchellus (Lucas, 1846); P. punctiger (O. Pickard-Cambridge, 1908); P. ruficapillus (Simon, 1885); P. simoni (Mello-Leitão, 1929) and $P$. wunderlichi (Muster et Thaler, 2007). Most of the Pulchellodromus species are known from the Mediterranean Region, except for $P$. medius that extends its range to the Caucasus, $P$. ruficapillus going to western Kazakhstan, and $P$. mainlingensis that is known from Tibet [Kastrygina, Kovblyuk, 2014; WSC, 2016]. Recently, the genus was well described and diagnosed by Muster et al. [2007: sub the pulchellus species group], Wunderlich [2012] and Kastrygina, Kovblyuk [2014]. All the Mediterranean species were revised by Muster et al. [2007]. The aim of this paper is to describe and diagnose a new Pulchellodromus species, which has been found in the newly collected spider materials from Navarre, Spain.

\section{Material and methods}

The material was collected during the 7th Field Workshop of the European Dry Grass Group (since 2015, the Eurasian DGG) on 16-23 June 2014 in Navarre, Spain [Biurrun et al., 2014].

The holotype and one paratype have been deposited in the Zoological Museum of the Moscow State University, Moscow, curator K.G. Mikhailov (ZMMU). Other paratypes are deposited in the Museum of Nature of the V.N. Karazin Kharkiv National University, Kharkiv, Ukraine, curator I.A. Muravjova (MNKhNU).

Drawings were made under both stereoscopic and brightfield microscopes by using a grid method. Illustrations of the epigynes were made after maceration in a $20 \%$ $\mathrm{KOH}$ water solution. All scale bars are equal to $0.1 \mathrm{~mm}$.

The terminology follows Muster et al. [2007]. Abbreviations used in the figure plates and text are as follows: Pedipalp: $b E$ - basal embolus; $C o-$ conductor; $C o P$ - conductor process; $C y P$ - cymbial process; $d E$ - distal embolus; $P E P$ - paraembolar projection of the embolus; RTA - retrolateral tibial apophysis; VTA - ventral tibial apophysis. Epigynevulva: $C D$ - copulatory duct; $E F$ - epigynal fold; $F D$ - fertilization duct; $G H$ - glandular head; $G M-$ glandular mound; $M S$ - median septum; $R$ - receptaculum. Leg spination: a - apical, d - dorsal, $\mathrm{p}$ prolateral, $\mathrm{r}$ - retrolateral, $\mathrm{v}$ - ventral. Leg segments were measured after their separation from the carapace. The format of measurements follows Muster et al. [2007]. All measurements are in millimeters. 

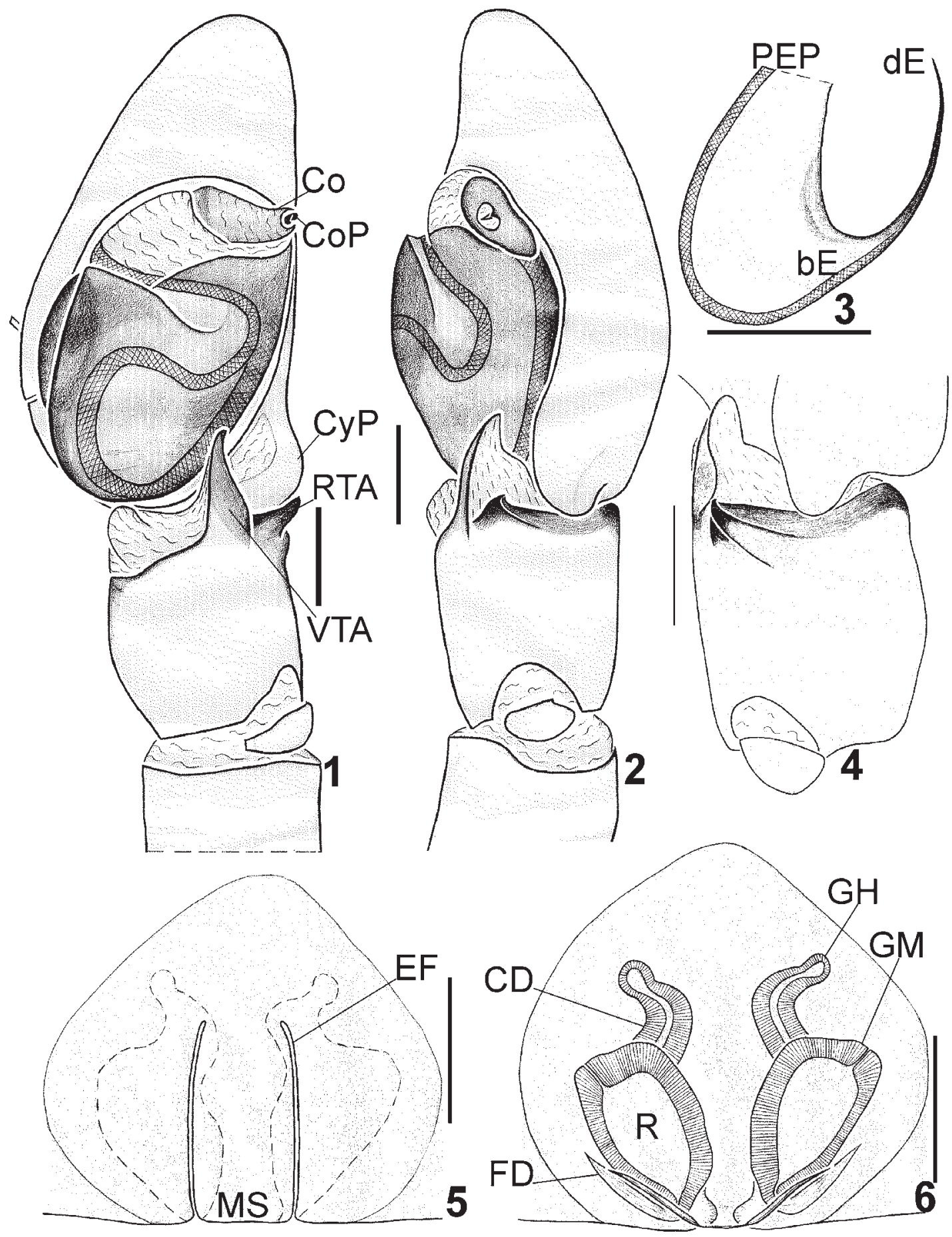

Figs 1-6. Male and female of Pulchellodromus navarrus sp.n.: 1 - palp, ventral view; 2 - palp, retrolateral view; 3 - embolus, dorsal view; 4 - tibia, dorso-retrolateral view; 5 - epigyne, ventral view; 6 - epigyne, dorsal view. Scale bars: $0.1 \mathrm{~mm}$.

Abbreviations: $b E$ - basal embolus; $C D$ - copulatory duct; $C o$ - conductor; $C o P$ - conductor process; $C y P$ - cymbial process; $d E$ — distal embolus; $E F$ - epigynal fold; $F D$ - fertilization duct; $G H$ - glandular head; $G M$ - glandular mound; $M S$ - median septum; PEP — paraembolar projection of the embolus; $R$ - receptaculum; RTA — retrolateral tibial apophysis; VTA — ventral tibial apophysis.

Рис 1-6. Самец и самка Pulchellodromus navarrus sp.n.: 1 - пальпа вентрально; 2 - пальпа ретролатерально; 3 - эмболюс дорсально; 4 - голень дорсо-ретролатерально; 5 - эпигина, вентрально; 6 - эпигина, дорсально. Масштаб: 0,1 мм.

Обозначения: $b E$ - начало (основание) эмболюса; $C D$ - копулятивный канал; $C o-$ кондуктор; $C o P$ - вырост кондуктора; $C y P$ - вырост цимбиума; $d E$ - дистальная часть эмболюса; $E F$ - щель эпигины; $F D$ - оплодотворительный канал; $G H-$ головковидная железа; $G M$ - холмовидная железа; $M S$ - медиальная пластинка; $P E P$ — проекция эмболюса; $R$ - рецептакула; $R T A$ - ретролатеральный отросток голени; VTA — вентральный отросток голени. 

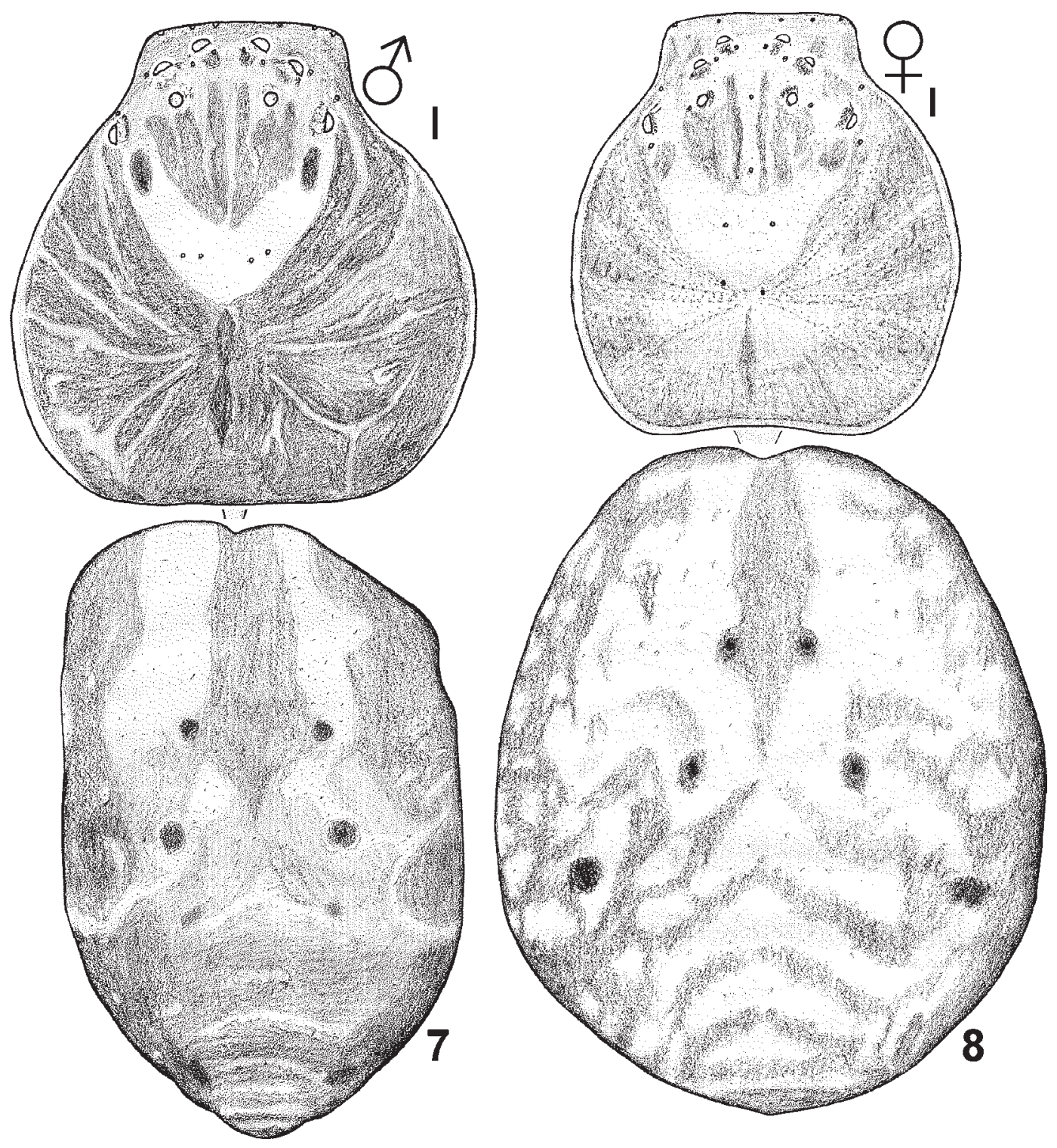

Figs 7-8. Habitusof Pulchellodromus navarrus sp.n., dorsal : 7 - male; 8 - female Scale bars: $0.1 \mathrm{~mm}$.

Рис. 7-8. Габитус Pulchellodromus navarrus sp.n. дорсально: 7 - самец; 8 - самка. Масштаб: 0,1 мм.

Habitat characteristics are given after Berastegi [2013] and the relevé descriptions performed during the Field Workshop.

\section{Description}

\section{Pulchellodromus navarrus sp.n. Figs $1-8$.}

MATERIAL. Holotype $0^{\top}$ (ZMMU) from Spain, Navarre, Iza $\left(42^{\circ} 50^{\prime} 27^{\prime \prime} \mathrm{N}, 1^{\circ} 43^{\prime} 47^{\prime \prime} \mathrm{E}\right), 436 \mathrm{~m}$ a.s.l., middle $9^{\circ}$ slope with the occasionally grazed steppe vegetation, Brachypodium phoenicoides community (class Festuco-Brometea), 18.06.2014, N.Yu. Polchaninova. - Paratypes: 1 \& (ZMMU), together with the holotype; 1 $0^{\prime \prime}, 1$ ( a.s.l., eroded $30^{\circ}$ slope with the steppe vegetation, abandoned pasture, Brachypodium retusum community (class Festuco-Ononidetea), 17.06.2014, N.Yu. Polchaninova.

ETYMOLOGY. The specific epithet is a Latin adjective related to the name of Navarre, the Autonomous Community of Spain.

DIAGNOSIS. By the shape of tibial apophyses, the male palp of $P$. navarrus sp.n. is most similar to that of P. pulchellus [cf. Muster et al., 2007: figs 7, 29], but can be distinguished by the long and narrow conductor (wide and globular in $P$. pulchellus), and by the presence of conductor process (absent in P. pulchellus). The epigyne of $P$. navarrus sp.n. is similar to those of $P$. glaucinus and P. wunderlichi [cf. Muster et al., 2007: figs 37-38], but differs in the conformation of the median septum covering about $1 / 4$ part of the re- 
ceptaculum (about $1 / 2$ part in $P$. glaucinus and $P$. wunderlichi), and in the receptaculae being more spaced apart from each other than those in $P$. glaucinus and $P$. wunderlichi.

DISTRIBUTION. The type locality only: Iza, Navarre, Spain.

DESCRIPTION. Male (holotype and female paratype from ZMMU). Measurements $\left(\sigma^{\top} / q\right)$ : total length 3.4/3.8; carapace $1.4 / 1.4$ wide; cymbium length 0.6; femur I 1.5/1.4. Carapace and abdomen light brown, with a distinct pattern (see Figs 7-8). Abdomen with a fir-shaped pattern.

Paratypes (male and female from MNKhNU). Measurements $\left(\sigma^{\top} / q\right)$ : total length $2.7 / 3.5$; carapace $1.2 / 1.2$ wide and 1.0/1.3 long. Length of legs and spination see in Tables $1-3$.

HABITAT. The studied specimens were collected from insolated slopes with the steppe vegetation.

PHENOLOGY. $0^{7}+$ - VI.

ACKNOWLEDGMENTS. We wish to cordially thank Idoia Biurrun (University of the Basque Country), the principal organizer of the Field Workshop, for providing results of the relevé descriptions, the Workshop international team for cooperation, and P.E. Gol'din (Kiev) for the linguistic proofreading of the earlier draft. Special thanks go to D.V. Logunov (Manchester, UK) for editing the English of the final draft.

\section{References}

Berastegi A. 2013. Pastizales y prados en Navarra: descripción, tipificación y ecología // Guineana. Vol.19. P.1-510.

Biurrun I., García-Mijangos I., Berastegi A., Ambarli D., Dembicz I., Filibeck G., Jandt U., Janisová M., Jaunatre R., Kacki Z., Kuzemko A., Pedashenko H., Polchaninova N., Vynokurov D., Dengler J. 2014. Diversity of dry grasslands in Navarre (Spain). Experiences from the 7th EDGG Field Workshop, 15-24 June 2014 // Bulletin of the European Dry Grassland Group. No.24/ 25. P.4-18.

Kastrygina Z.A., Kovblyuk M.M. 2014. The spider genus Pulchellodromus Wunderlich, 2012 in the Crimea (Aranei: Philodromidae) // Arthropoda Selecta. Vol.23. No.3. P.279-283.

Muster C., Bosmans R., Thaler K. 2007. The Philodromus pulchellus-group in the Mediterranean: taxonomic revision, philogenetic analysis and biogeography (Araneae: Philodromidae) // Invertebrate Systematics. Vol.21. P.39-72.
Table 1. Length of leg segments of Pulchellodromus navarrus sp.n. $\left(\mathrm{O}^{\top} /{ }^{\circ}\right)$.

Таблица 1. Длина сегментов ног Pulchellodromus navarrus sp.n. $\left(\sigma^{7} / 9\right)$.

\begin{tabular}{|l|c|c|c|c|c|c|}
\hline Leg & Femur & Patella & Tibia & Metatarsus & Tarsus & Total \\
\hline I & $1.1 / 1.2$ & $0.5 / 0.6$ & $0.9 / 0.9$ & $0.8 / 0.8$ & $0.6 / 0.6$ & $3.9 / 4.1$ \\
\hline II & $1.2 / 1.4$ & $0.5 / 0.6$ & $1.1 / 1.1$ & $0.9 / 0.9$ & $0.6 / 0.6$ & $4.3 / 4.6$ \\
\hline III & $1.0 / 1.2$ & $0.4 / 0.6$ & $0.8 / 0.9$ & $0.7 / 0.7$ & $0.4 / 0.5$ & $3.3 / 3.9$ \\
\hline IV & $1.0 / 1.2$ & $0.4 / 0.5$ & $0.8 / 0.8$ & $0.7 / 0.8$ & $0.4 / 0.5$ & $3.3 / 3.8$ \\
\hline
\end{tabular}

Table 2. Male leg spination of Pulchellodromus navarrus sp.n.

Таблица 2. Шипование ног самца Pulchellodromus navarrus sp.n.

\begin{tabular}{|l|l|l|l|}
\hline Leg & Femur & Tibia & Metatarsus \\
\hline I & d 1-1, p 1-1-1 & $\begin{array}{l}\text { d 1, p 1-1-1, } \\
\text { r 1-1-1, v 2-2-2a }\end{array}$ & $\begin{array}{l}\text { p 1-1-1, } \\
\text { r 1-1-1, v 2-2 }\end{array}$ \\
\hline II & d 1-1-1 & $\begin{array}{l}\text { d 1, p 1-1-1, } \\
\text { r 1-1-1, v 2-2-2a }\end{array}$ & $\begin{array}{l}\text { p 1-1-1, } \\
\text { r 1-1-1, v 2-2-2a }\end{array}$ \\
\hline III & d 1-1 & $\begin{array}{l}\text { d 1, p 1-1, } \\
\text { r 1-1-1, v2-2-2a }\end{array}$ & $\begin{array}{l}\text { p 1-1-1-1, } \\
\text { r 1-1, v 2-2-1-1 a }\end{array}$ \\
\hline IV & d 1-1 & $\begin{array}{l}\text { d 1-1, p 1-1, } \\
\text { r 1-1, v 2-2-2a }\end{array}$ & $\begin{array}{l}\text { p 1-1-1-1, } \\
\text { r 1-1-1-1, v 2-2-1a }\end{array}$ \\
\hline
\end{tabular}

Table 3. Female leg spination of Pulchellodromus navarrus sp.n.

Таблица 3. Шипование ног самки Pulchellodromus navarrus sp.n.

\begin{tabular}{|l|l|l|l|}
\hline Leg & Femur & Tibia & Metatarsus \\
\hline I & d 1-1, p 1-1 & $\begin{array}{l}\text { p 1-1, r 1-1, } \\
\text { v 2-2-1 a }\end{array}$ & $\begin{array}{l}\text { p 1-1-1, r 1-1-1, } \\
\text { v 2-2 }\end{array}$ \\
\hline II & d 1 & $\begin{array}{l}\text { p 1-1, r 1-1, } \\
\text { v 2-2-1 a }\end{array}$ & $\begin{array}{l}\text { p 1-1-1, r 1-1-1, } \\
\text { v 2-2 }\end{array}$ \\
\hline III & d 1-1 & $\begin{array}{l}\text { p 1-1, r 1-1, } \\
\text { v 2-2 }\end{array}$ & $\begin{array}{l}\text { p 1-1-1, r 1-1-1, } \\
\text { v 2-2-1 a }\end{array}$ \\
\hline IV & \multicolumn{3}{|c|}{ Leg IV is missing } \\
\hline
\end{tabular}

WSC 2016. World Spider Catalog. Natural History Museum Bern, online at http://wsc.nmbe.ch, version 17.0 (accessed on 29.01.2016).

Wunderlich J. 2012. Contribution to taxonomy and evolution of the european genera of the spider family Philodromidae (Araneae) // Beiträge zur Araneologie. Vol.7. P.25-56.

Responsible editor D.V. Logunov 